Dagmara Stangierska

Accepted: 09.05.2021

Dawid Olewnicki

Ewa Sabata

Warsaw University of Life Sciences

\title{
FINANCIAL-ECONOMIC ANALYSIS OF FRUIT AND VEGETABLE PRODUCER GROUPS IN POLAND, AND CONDITIONS FOR THE FUNCTIONING OF PRODUCER GROUPS
}

Poland occupies a high position in both global and European fruit and vegetable production. The large number of small-sized farms has been one of the problems of Polish agriculture for years. National and EU financial help has increased interest in associating producers into groups. The effective functioning of these groups is conditioned by many factors related to the specificity of horticultural production, legislation and the market situation. Organizations on the fruit and vegetable market show significant variation in functioning as well as in the production and economic results achieved.

The aim of the article is to assess the financial and economic situation and provide strategic analysis of the conditions for the operation of fruit and vegetable producer groups in Poland. Research was conducted on the basis of data contained in the financial statements from 2016-2017 and the financial liquidity and profitability ratios calculated on their basis. A general assessment of the conditions needed for the functioning of producer groups is also presented in the paper.

Low profitability and financial liquidity of producer groups were noted in the analyzed years. Key strategic factors for the functioning of producer groups included: the visible impact of financial assistance, the functioning of producer groups and economies of scale resulting from greater aggregation of competition, and the fact that farmers are still reluctant to associate and often have limited business competences to run producer groups.

Key words: producer group, producer organizations, fruit and vegetable market, financial analysis, ratio analysis.

JEL Codes: D22, D24,Q14, Q13

\section{Introduction}

Modern fruit and vegetable producers face many challenges and difficulties, despite the fact that production technologies have changed dramatically in the last few decades. Poland is at the forefront of European and even world production of many fruit and vegetable species. Still, part of Polish fruit and vegetable production does not meet the 
requirements of foreign markets due to qualitative reasons. One of the problems of Polish agriculture continues to be fragmentation, which is a major impediment to development and competitiveness. The solution to this problem may be cooperation, which usually takes the form of fruit and vegetable producer groups and organizations. Producer groups can also count on additional financial support from the European Union, thanks to which farms can be modernized. EU and national legislation governing the functioning of such entities has changed several times in recent years, which could be a source of problems in the functioning of these entities.

A pre-recognized producer group is an organizational unit that brings together farmers producing fruit and vegetables, with legal personality and the status of preliminary recognition granted by the marshal of the voivodeship competent for the seat of the group, in accordance with the provisions of national law and EU law. A group of fruit and vegetable producers must obtain pre-recognition status to meet the relevant criteria. The association of fruit and vegetable producers must be created with at least 5 members who jointly generated and sold, in the year preceding the year of application submission, products worth a minimum of 50,000 EUR. In addition, a group applying for pre-recognition status must provide a recognition plan divided into annual implementation periods. The duration of the plan implementation may not exceed a period of five years from the date of approval by the voivodeship marshal who is responsible for the seat of the group ${ }^{1}$.

Interest in creating groups among producers in recent years has been great, because such cooperation brings many benefits. It allows to collect large batches of equal quality products, thus increasing competitiveness on domestic and foreign markets. As Malinger $^{2}$ points out in theory, competitiveness is determined by cost measures: profitability, efficiency and effectiveness. Profitability is associated not only with production costs, but also with revenues. Profitability can be described as the difference between revenues and costs. For productivity, the European Commission defines this as the most reliable measure over a long period of time.

The aim of the article is to assess the economic and financial situation and provide strategic analysis of the conditions for the operation of fruit and vegetable producer groups in Poland. Research was conducted on the basis of data contained in the financial statements of selected groups of fruit and vegetable producers from 2016-2017, and the financial liquidity and profitability ratios calculated on their basis. The analyses took into account the current basic legislation regulating the functioning of the fruit and vegetable market. In addition, an assessment of the conditions for the functioning of producer groups was carried out, which aims to determine external and internal factors, both positive and negative, which affect the situation of producer groups.

\footnotetext{
${ }^{1}$ K. Krzyżanowska: Stan zorganizowania rolników w grupy producentów owoców i warzyw w Polsce, Roczniki Naukowe SERIA, XIII(2), 2011, s. 256-260.

${ }^{2} \mathrm{~J}$. Malinger: Wyniki ekonomiczne uznanych organizacji producentów jabłek z powiatu grójeckiego. Roczniki Naukowe SERIA, XVIII(1), 2016, s. 169-173.
} 


\section{Material and Methodology}

To analyze the financial situation, 19 groups of fruit and vegetable producers were selected from the register kept by the President of ARMA, and then financial statements were obtained from the EMIS database. The selection criteria included: the category of activity (9 groups with fruit production, 10 groups with vegetable production) and the availability of financial statements for 2016 (R1) and 2017 (R2). Group names have been replaced by codes, where GPO - Fruit Producer Group, GPW - Vegetable Producer Group; the groups were given consecutive numbers. The main area of activity according to the NAICS classification was in most cases wholesale of fresh fruit and vegetables. All analyzed groups were limited liability companies, only GPW2 was organized in the form of a cooperative. Groups of fruit producers had a larger number of members; only two entities had less than 10 members (GPO3 and GPO5), while in 8 GPW the number of members ranged from 5 to 9 (Table 1 ).

Table 1. Characteristics of selected groups of fruit and vegetable producers and their economic and financial situation

\begin{tabular}{|c|c|c|c|c|c|}
\hline \multirow{2}{*}{$\begin{array}{c}\text { Producers group } \\
\text { code }\end{array}$} & \multirow[b]{2}{*}{$\begin{array}{c}\text { Number of } \\
\text { members }\end{array}$} & \multicolumn{2}{|c|}{ Net revenue } & \multicolumn{2}{|c|}{ Net profit / loss } \\
\hline & & $\begin{array}{l}\mathrm{R} 2 \text { (in PLN } \\
\text { thousand) }\end{array}$ & $\begin{array}{l}\text { \% change } \\
(\mathrm{R} 2 / \mathrm{R} 1)\end{array}$ & $\begin{array}{l}\text { R2 (in PLN } \\
\text { thousand) }\end{array}$ & $\begin{array}{l}\% \text { change } \\
(\mathrm{R} 2 / \mathrm{R} 1)\end{array}$ \\
\hline GPO1 & $>25$ & 16955,00 & $-4,4$ & $-588,00$ & $-233,3$ \\
\hline GPO2 & $10-25$ & 9246,00 & 0,4 & $-493,00$ & $-15,9$ \\
\hline GPO3 & $<10$ & 23313,00 & 13,2 & $-832,00$ & $-109,6$ \\
\hline GPO4 & $>25$ & 12318,00 & 35,9 & 994,00 & 942,4 \\
\hline GPO5 & $<10$ & 7975,00 & 43,1 & 136,00 & $-73,4$ \\
\hline GPO6 & $>25$ & 3296,00 & $-27,2$ & $-72,00$ & $-641,4$ \\
\hline GPO7 & $10-25$ & 8678,00 & $-1,7$ & 17,00 & $-90,9$ \\
\hline GPO8 & $>25$ & 9659,00 & $-24,9$ & 57,00 & $-27,2$ \\
\hline GPO9 & $>25$ & 22024,00 & 42,2 & 441,00 & 210,6 \\
\hline Avarage GPO & - & 12607,11 & $8,5 \%$ & $-37,78$ & $-185,8 \%$ \\
\hline GPW1 & $<10$ & 4687,00 & 4,7 & $-589,00$ & 20,8 \\
\hline GPW2 & $<10$ & 20764,00 & 7,9 & 802,00 & 214,5 \\
\hline GPW3 & $<10$ & 1034,00 & $-28,0$ & $-12,00$ & $-136,4$ \\
\hline GPW4 & $<10$ & 3091,00 & 5,8 & 36,00 & $-52,0$ \\
\hline GPW5 & $<10$ & 3812,00 & 8,9 & $-358,00$ & 40,1 \\
\hline GPW6 & $>25$ & 17600,00 & $-14,0$ & 154,00 & 130,0 \\
\hline GPW7 & $<10$ & 14898,00 & $42,7 \%$ & $-88,00$ & 46,7 \\
\hline GPW8 & $<10$ & 65432,00 & $-0,7$ & 17,00 & $-91,1$ \\
\hline GPW9 & $10-25$ & 8867,40 & $-5,7$ & 5,05 & $-92,2$ \\
\hline GPW10 & $<10$ & 13070,48 & 10,3 & $-2729,24$ & $-88,4$ \\
\hline Avarage GPW & - & 15325,59 & $3,2 \%$ & $-589,00$ & 20,8 \\
\hline
\end{tabular}

Source: authors' own study based on data from the EMIS database. 
For the purpose of preliminary analysis, selected data from the balance sheet and profit and loss account were obtained from the producer groups' financial statements included in the EMIS database. The data collected in the balance sheet and profit and loss account are the basis for calculating financial indicators that allow the assessment of the past and present situation of the enterprise and are an important tool in management and planning. In order to characterize the economic and financial situation of enterprises, the value of net income and net profit / loss in 2017 was analyzed (Table 1). The article also presents the values of financial liquidity and profitability ratios.

Financial liquidity ratios:

- Current liquidity ratio - percentage ratio of current liabilities to the value of current assets held,

- Fast liquidity ratio - the percentage ratio of current liabilities to the value of current assets, less inventories and short-term settlements,

- Cash liquidity ratio - percentage ratio of current liabilities to available Cash Profitability ratios:

- Profitability of revenues (ROS) - percentage ratio of net profit / loss to sales revenues

- Return on assets (ROA) - the ratio of net profit / loss to the average value of total assets

- Return on equity (ROE) - the ratio of net profit / loss to equity ${ }^{3}$.

\section{Characteristics of the research sample - the amount of revenue and net profit / loss}

Revenues are defined as economic benefits generated as a result of a company's operations, affecting the increase of equity. Net revenues are revenues from the sale of goods and services excluding $\mathrm{VAT}^{4}$. In the case of fruit producer groups, the value of revenue in 2017 ranged from PLN 3.3 million up to PLN 23.3 million, while the revenues of vegetable producer groups ranged from about PLN 1 million up to approx. PLN 65.5 million. The average revenue of vegetable producer groups was higher than the average revenue of fruit producer groups by almost PLN 3 million; however, the increase in revenues compared to the previous year was higher for fruit producer groups. The largest increase compared to 2016 was recorded for GPO5 and GPO9 (by over $40 \%$ ). In the case of GPO6 and GPO8, net revenues in 2017 decreased by over $20 \%$. There were slight changes in the volume of revenues over the analyzed years. Only GPW7 recorded a larger increase of over 40\%, while GPW3's revenues decreased by nearly $30 \%$ (Table 1 ).

\footnotetext{
${ }^{3}$ L. Bednarski: Analiza finansowa w przedsiębiorstwie. Państwowe Wydawnictwo Ekonomiczne 2007.

${ }^{4}$ T. Martyniuk: Przychody jako kategoria prawa bilansowego. Zeszyty Teoretyczne Rachunkowości, 54. 2010, s.117-128
} 
After taking into account other revenues, operating costs, revenues, financial costs, extraordinary profits and losses, the net financial result is finally obtained. Groups of fruit producers achieved an average net loss while vegetable producers obtained an average net profit which was $20 \%$ higher compared to the previous year. Among the groups of fruit producers selected for analysis, GPO4 achieved the highest net profit which was higher by approx. 950\% compared to the previous year. Half of the selected groups of vegetable producers achieved a loss on sales, and the net financial result was in the range of PLN 2.7 million losses (GPW10) up to approx. PLN 800 thousand profit (GPW2). Among the groups listed below, there were major changes between the financial results obtained in 2016 and 2017 (Table 1).

\section{Results}

One of the first analyzed indicators was the current liquidity ratio, which indicates a company's ability to pay its current liabilities by liquidating current assets. The most favorable situation is when its value is in the range of 1.2 to 2.0. Too high a value indicates insufficient efficiency in the use of property resources. However, a value lower than 1.2 may indicate a threat to the entity's solvency ${ }^{5}$. Among the groups of fruit producers, the most optimal values were recorded for GPO6 and GPO3. For GPO1, the current liquidity in 2016-2017 was 1.25 and 1.16, respectively, so it was close to the threat threshold. All other analyzed groups of fruit producers recorded values below this threshold. Among the groups of vegetable producers, optimal current liquidity was recorded at GPW10 in 2017. In 2016, it also had a value above the threat threshold. GPW3 and GPW7 were also in a favorable situation. The current liquidity of other groups was below 1.2 and was a threat to timely payment of their liabilities.

When calculating the quick liquidity ratio, inventories and accruals are excluded from current assets. In the case of quick liquidity, in addition to the value of the indicator, payment terms are also taken into account ${ }^{6}$. The highest values were recorded in both analyzed years in GPO3. At the same time, this group had high current liquidity. This may indicate that the funds are amassed excessively in bank accounts. The situation of GPO6 and GPO7, with relatively high current liquidity, quick liquidity is quite low, which may mean that the group has accumulated a large amount of stocks in which funds were frozen. The quick liquidity ratio in the years 2016-2017 remained at the correct level for GPW7 and GPW10. In 2017, the GPW9 saw an increase in current and quick liquidity to 1.13 , therefore the group achieved the ability to quickly cover current liabilities. In 2017, the current and quick liquidity of the GPW9 increased to 1.13, and therefore the group achieved the ability to quickly cover its current liabilities. In case of GPW3 in 2016, the indicator was 1.03, but in the following year it decreased twice. Also in the case of GPW8 there was a significant fall in the quick ratio.

${ }^{5}$ J. Dyktus, M. Gaertner, B. Malik: Sprawozdawczość i analiza finansowa. Difin, 2017.

${ }^{6}$ L. Bednarski: Analiza finansowa w przedsiębiorstwie. Państwowe Wydawnictwo Ekonomiczne, 2007. 
Table 2. Liquidity ratios for selected groups of fruit producers in 2016-2017

\begin{tabular}{|c|c|c|c|c|c|c|}
\hline \multirow{2}{*}{$\begin{array}{l}\text { Producer group } \\
\text { code }\end{array}$} & \multicolumn{2}{|c|}{ Current liquidity } & \multicolumn{2}{|c|}{ Quick liquidity } & \multicolumn{2}{|c|}{ Cash liquidity } \\
\hline & R1 & $\mathrm{R} 2$ & R1 & $\mathrm{R} 2$ & R1 & $\mathrm{R} 2$ \\
\hline GPO1 & 1,25 & 1,16 & 1,15 & 0,60 & 0,08 & 0,00 \\
\hline GPO2 & 0,99 & 0,88 & 0,88 & 0,86 & 0,10 & 0,03 \\
\hline GPO3 & 1,82 & 1,24 & 1,78 & 1,17 & 1,63 & 1,07 \\
\hline GPO4 & 0,69 & 0,98 & 0,31 & 0,37 & 0,01 & 0,01 \\
\hline GPO5 & 0,32 & 0,87 & 0,31 & 0,87 & 0,01 & 0,15 \\
\hline GPO6 & 1,48 & 1,63 & 0,58 & 0,52 & 0,14 & 0,05 \\
\hline GPO7 & 1,03 & 0,99 & 0,30 & 0,26 & 0,01 & 0,00 \\
\hline GPO8 & 0,36 & 0,55 & 0,35 & 0,38 & - & - \\
\hline GPO9 & 0,60 & 1,03 & 0,51 & 0,97 & 0,07 & 0,04 \\
\hline Avarage & 0,95 & 1,04 & 0,69 & 0,67 & 0,26 & 0,17 \\
\hline GPW1 & 0,74 & 0,54 & 0,51 & 0,37 & 0,46 & 0,12 \\
\hline GPW2 & 0,89 & 1,10 & 0,51 & 0,59 & 0,07 & 0,02 \\
\hline GPW3 & 1,45 & 1,04 & 1,03 & 0,54 & 1,00 & 0,46 \\
\hline GPW4 & 0,15 & 0,09 & 0,05 & 0,04 & - & - \\
\hline GPW5 & 0,83 & 0,94 & 0,83 & 0,94 & - & - \\
\hline GPW6 & 0,81 & 0,67 & 0,81 & 0,66 & 0,06 & 0,01 \\
\hline GPW7 & 1,15 & 1,26 & 1,14 & 1,25 & 0,33 & 0,37 \\
\hline GPW8 & 0,89 & 0,22 & 0,69 & 0,20 & 0,03 & 0,03 \\
\hline GPW9 & 0,92 & 1,13 & 0,82 & 1,13 & 0,51 & 0,56 \\
\hline GPW10 & 1,29 & 1,57 & 1,03 & 1,03 & 0,38 & 0,22 \\
\hline Avarage & 0,91 & 0,86 & 0,74 & 0,68 & 0,36 & 0,22 \\
\hline
\end{tabular}

Source: authors'own study based on data from the EMIS database.

The cash liquidity indicates the amount of current liabilities that can be covered with the available cash ${ }^{7}$. GPO3 had very high cash liquidity, so it can be concluded that it had no problems with settling current liabilities. GPO1, despite its fairly good ability to settle its liabilities by liquidating current assets, did not have cash liquidity in 2017 , which means that it had no cash at its disposal. However, it was solvent (Table 2).

GPW4 had a very low capacity to cover liabilities, taking into account both analyzed indicators. Cash liquidity among vegetable producer groups was very diversified. A low value was recorded in the case of GPW2, GPW6 and GPW8. For GPW4 and GPW5 there was no data on this subject in the available reports. In other cases, cash liquidity was at a good level. GPW3 was able to cover all its current liabilities with available cash in 2016, so there was no risk of its insolvency (Table 2).

Return on assets (ROA) is the ratio of net profit / loss to the average value of total assets. You can use it to determine what financial result the company is able to generate with the available assets. Return on equity (ROE) is an indicator showing the ability to generate profits or losses shown by the equity capital involved. Profitability ratios do not have the recommended values. Their values can be compared with other

${ }^{7}$ L. Bednarski: Analiza finansowa ... op.cit. 
companies from a given sector ${ }^{8}$. In the years 2016-2017, the ROA value in fruit producer groups ranged from $-4.20 \%$ (GPO2) to $6.01 \%$ (GPO4) and increased in this period only for GPO4 and GPO9. For GPO2 and GPO3, the negative value of the indicator was maintained in both examined years. Only GPO4 and GPO9 at the turn of 2016-2017 increased the profitability of their assets. In the case of vegetable producer groups, a large variation in the value of ROA can be observed. For GPW3, the highest return on assets was recorded among the groups listed in Table 3 in 2017 (approx. 65\%), with the lowest value in 2017 (approx. $-39 \%$ ), which is related to the financial results of the entity. ROA of all of the above entities was low. In the case of GPW1 and GPW5, it remained at around $-10 \%$.

The net return on equity (ROE), also known as financial profitability, shows the percentage of net profit to equity. Its high or growing value proves the effectiveness of investment activities and the involved equity ${ }^{9}$. Among the selected groups of fruit producers, the ROE value increased in 2017 compared to the previous year; in the case of GPO4 and GPO9, it amounted to approx. 30\%. The financial profitability of GPO3 was very unfavorable. In 2017 , it was $-445 \%$. GPO1, GPO2 and GPO6 also had a negative value of the index. This points to ineffective management of own capital and constitutes a barrier to their development. This situation may also be related to the capital intensity of horticultural production ${ }^{10}$. The ROE of fruit producer groups deteriorated significantly in 2017. The financial profitability of vegetable producer groups was diversified. In the analyzed period, the GPW1 recorded an increase from $486.27 \%$ to $135.09 \%$. The situation of the GPW3 was different. ROE fell significantly from $165.00 \%$ to $-171.43 \%$. The value of this ratio at the GPW10 in the analyzed years remained at a constant, high level of approx. 50\%. Thus, the GPW10 managed its equity properly.

The net profitability is the ratio of the earned profit / loss to the income after tax. In the case of GPO2 and GPO3, the indicator remained at a low, negative level in the analyzed years, while in the case of GPO1 and GPO6 its value decreased significantly. The maximum value of the net return on sales was approx. 9\% for GPO5 in 2016 and approx. $8 \%$ for GPO4 in 2017, which means about 0.08-0.09 PLN of profit per 1 PLN of revenue. The lowest value of this indicator in both years was recorded for GPO2 (approx. -5\%). The sale generated losses or low profits and therefore was ineffective. The average net profitability of fruit producer groups slightly decreased at the turn of 2016-2017. Profitability on net sales among vegetable producer groups was low, especially at the GPW10, GPW1, GPW5, where it was below -10\%, and in 2017 it was close to $-30 \%$ on the GPW 10 . The net profitability of GPW2 in 2017 was $3.86 \%$, which was the highest value among the groups presented in Table 3.

\footnotetext{
${ }^{8}$ J. Dyktus, M. Gaertner, B. Malik: Sprawozdawczość... op.cit.

${ }^{9}$ L. Bednarski: Analiza finansowa... op.cit.

10 O. Stefko: Płynność finansowa gospodarstw ogrodniczych a zmiany zachodzące na rynku międzynarodowym. Problems of World Agriculture/Problemy Rolnictwa Światowego, 16, 2016, s. 325-334.
} 
Table 3. Profitability ratios of selected groups of fruit and vegetables producers in 2016-2017

\begin{tabular}{|c|c|c|c|c|c|c|}
\hline \multirow{2}{*}{$\begin{array}{l}\text { Producer } \\
\text { group code }\end{array}$} & \multicolumn{2}{|c|}{$\begin{array}{c}\text { Return on assets } \\
\text { (ROA) }(\%)\end{array}$} & \multicolumn{2}{|c|}{$\begin{array}{l}\text { Return on equity } \\
\text { (ROE) }(\%)\end{array}$} & \multicolumn{2}{|c|}{$\begin{array}{l}\text { Net return on sales } \\
\quad(\text { ROS })(\%)\end{array}$} \\
\hline & R1 & $\mathrm{R} 2$ & R1 & R2 & R1 & R2 \\
\hline GPO1 & 0,75 & $-0,93$ & 19,82 & $-32,04$ & 2,49 & $-3,47$ \\
\hline GPO2 & $-3,30$ & $-4,20$ & $-25,88$ & $-42,87$ & $-4,62$ & $-5,33$ \\
\hline GPO3 & $-1,24$ & $-2,62$ & $-38,96$ & $-444,92$ & $-1,93$ & $-3,57$ \\
\hline GPO4 & $-0,71$ & 6,01 & $-6,58$ & 35,65 & $-1,30$ & 8,07 \\
\hline GPO5 & 1,76 & 0,52 & 10,43 & 2,45 & 9,17 & 1,71 \\
\hline GPO6 & 0,13 & $-0,73$ & 3,08 & $-20,06$ & 0,29 & $-2,18$ \\
\hline GPO7 & 0,38 & 0,04 & 3,04 & 0,28 & 2,12 & 0,20 \\
\hline GPO8 & 0,08 & 0,07 & 1,74 & 1,25 & 0,61 & 0,59 \\
\hline GPO9 & 0,63 & 2,26 & 12,00 & 27,16 & 0,92 & 2,00 \\
\hline Avarage GPO & $-0,17$ & 0,05 & $-2,37$ & $-52,57$ & 0,86 & $-0,22$ \\
\hline GPW1 & $-10,07$ & $-8,30$ & $-486,27$ & 135,09 & $-16,62$ & $-12,57$ \\
\hline GPW2 & 0,56 & 1,80 & 4,19 & 11,63 & 1,33 & 3,86 \\
\hline GPW3 & 64,71 & $-38,71$ & 165,00 & $-171,43$ & 2,30 & $-1,16$ \\
\hline GPW4 & 0,45 & 0,26 & 13,11 & 6,38 & 2,57 & 1,16 \\
\hline GPW5 & $-11,82$ & $-8,74$ & 137,47 & 45,15 & $-17,08$ & $-9,39$ \\
\hline GPW6 & 0,35 & 1,25 & 6,47 & 12,00 & 0,33 & 0,88 \\
\hline GPW7 & $-3,39$ & $-2,18$ & $-13,26$ & $-7,61$ & $-1,58$ & $-0,59$ \\
\hline GPW8 & 0,19 & 0,02 & 9,23 & 0,78 & 0,31 & 0,03 \\
\hline GPW9 & 0,30 & 0,03 & 0,80 & 0,06 & 0,69 & 0,06 \\
\hline GPW10 & $-2,20$ & $-4,55$ & 49,19 & 48,08 & $-16,83$ & $-28,51$ \\
\hline Avarage PW & 3,91 & $-5,91$ & $-11,41$ & 8,01 & $-4,46$ & $-4,62$ \\
\hline
\end{tabular}

Source: authors' own study based on data from the EMIS database.

\section{Assessment of the conditions for the functioning of producer groups}

The basis of the common organization of the fruit and vegetable market, which is so important in Polish agriculture, is the horizontal cooperation of producers. It is defined as a union of enterprises belonging to the same production and distribution phase ${ }^{11,12}$. In

11 K. Załuska: Grupy wstępnie uznane i organizacje producentów na rynku owoców i warzyw w Polsce, Europie i na świecie. W: ABC organizacji i funkcjonowania grup producenckich. CDR w Brwinowie oddział w Radomiu, 2010.

12 J. Małysz: Integracja w Agrobiznesie. W: A. Woś (red.) Encyklopedia Agrobiznesu, Fundacja Innowacja. Warszawa, 1998 s. 389-391. 
the case of the agricultural sector, this means, in simplified terms, the joint action of producers producing the same products, while maintaining their autonomy ${ }^{13}$.

According to Hardaker and co-authors ${ }^{14}$, horizontal integration of producers helps to reduce business risk, including production, price, personnel and institutional risk; and financial risk relating to the methods of financing the farm and agricultural activity. As indicated by Klepacki and Krajewski ${ }^{15}$, producer groups now put emphasis on the development of logistics activities aimed at improving production and distribution. The integration of activities has a positive effect on the modernization of farms and changes in the structure of Polish agriculture. Although the cooperation of producers on the Polish agricultural market is becoming more and more common, besides numerous advantages, they also encounter barriers. The biggest problems include the lack of preparation of farmers to operate within a larger organization, conflicts and misunderstandings between members, loss of decision-making independence and lack of trust in this form of activity ${ }^{16}$.

In order to assess the conditions of the functioning of producer groups, external and internal factors were identified with a positive and negative impact on the functioning of the enterprise in order to assess its current condition and potential. These factors are grouped into four categories ${ }^{17}$.

Associated producers have a chance to collect large batches of goods of equal quality, which increases their bargaining power and makes it easier for them to obtain favorable prices, while reducing costs. There is also access to external financing sources, thanks to which farmers have a chance to invest in newer technologies and develop their farms. The association of producers definitely facilitates the introduction of goods to the market without intermediaries and their margins, and thus obtaining higher prices for the producer while maintaining an attractive price on the store shelf ${ }^{18}$. Such entities have greater economic power and market position than individual producers. They are able to create customer networks and build lasting market links. A single producer is not able to meet the requirements of retail chains in terms of the volume of supplies, and wellfunctioning groups of producers can become trading partners for large customers ${ }^{19}$, and also have a better negotiating position and the chance to be more price creators. Production in the organization is planned and adjusted to the demand in terms of quantity, which can be helpful in preventing overproduction and, consequently, food

13 I. Lipińska: Rola integracji poziomej w ograniczaniu występowania ryzyka produkcyjnego w kontekście reformy wspólnej polityki rolnej - aspekty prawne i ekonomiczne. Roczniki Naukowe SERIA XVI (5), 2014, s.139-145.

${ }^{14}$ J.B. Hardaker, R.B.M. Huirne, J.R. Anderson, G. Lien: Coping with Risk in Agriculture. CABI Publushing. Wallingford, 2004.

${ }^{15}$ B. Klepacki, J. Krajewski: Wykorzystanie środków pomocowych unii europejskiej w rozwoju infrastrtury logistycznej grup producenckich w ogrodnictwie. Roczniki Naukowe SERIA XVII (5), 2015, s. 136-140.

${ }^{16}$ R. Gąsior, A. Nowak: Integracja pozioma producentów rolnych - możliwości i bariery. Acta Oeconomia (51), 2017.

${ }^{17}$ Ł. Szałata, J. Zwoździak: Analiza SWOT jako podstawowe narzędziew zarządzaniu środowiskiem. Rocznik Ochrona Środowiska (Annual Set The Environment Protection), 13, 2011, s. 1105-1114.

18 W. Sobczak, L. Jabłońska, A. Dziedzic: Wybrane problemy funkcjonowania grup producentów owoców z regionu grójeckiego i rawskiego. Journal of Agribusiness and Rural Development, (03 [29]), 2013.

19 M. Domagalska-Grędys: Czynniki kształtujące zmianę dochodu współpracujących gospodarstw grup producenckich z województwa podkarpackiego. Rocz. Nauk Roln. 97, 4, 2010, s.45-53. 
waste $^{20}$. Groups often use measures to increase the added value of their production with the main goal of obtaining higher prices. Added value can be obtained in various ways. Groups of fruit and vegetables producers can use their products for processing, and thus expand their offer. They are able to obtain goods that meet the customer's expectations through the appropriate selection of varieties, including organic ones, preparation of fruit and vegetables directly for consumption, and appropriate packaging. Such marketing activities allow to gain consumer trust and build a recognizable brand ${ }^{21}$.

Among the threats it should be mentioned that the same mechanisms that support domestic producer groups provide support in other EU countries, and foreign affiliated and individual producers constitute significant competition for domestic producer groups. The available funds obtained whitin the CAP may ensure producers of public support and, after its discontinuation, cause deterioration of financial liquidity of producer groups. Significant weaknesses of the functioning of groups of fruit and vegetables producers in Poland are the aversion of Polish farmers to associate, and administrative barriers to creating and running a producer group ${ }^{22}$. Producer groups rarely have members with high managerial competences on their boards, who would make modern business decisions according to the production scale of the managed groups ${ }^{23}$ (Table 4).

The strengths are the combination of higher revenues and lower costs, which ultimately allow the producer to obtain higher income and stabilize the organization's position on the market. The research conducted by Gąsior and Nowak ${ }^{24}$ among farmers from the Lubelskie voivodeship, and by Olewnicki, Jabłońska and Marzec ${ }^{25}$ among members of producer groups from the Grójec and Rawa poviats, shows that the most important benefits resulting from the joint organization are the improvement of production quality and better sales conditions, brand creation, better promotion, improved competitive position, lower business risk, joint investments and purchase of means of production, as well as better access to market information ${ }^{26}$. The fruit and vegetable producer groups have an impact on the development of rural areas. They also create new jobs for the rural population.

${ }^{20}$ W. Boguta: Grupy i organizacje producentów owoców i warzyw. Przewodnik praktycznego stosowania obowiązującego prawa (według stanu na dzień 01 września 2004 roku). Wydawnictwo Akademii Rolniczej w Lublinie, 2004.

21 J. Kania, W. Musiał: Dodawanie wartości w łańcuchach dostaw żywności-studium przypadku. Roczniki Naukowe Stowarzyszenia Ekonomistów Rolnictwa i Agrobiznesu, 19(6), 2017, s. 105-110.

${ }^{22}$ D. Olewnicki, J. Rybak: Rodzaje uprzedzeń właścicieli gospodarstw ogrodniczych do zrzeszania się w grupy producentów - przykład gminy Błędów Zeszyty Naukowe SGGW - Ekonomika i Organizacja Gospodarki Żywnościowej, 101, 2013, s. 129-138.

${ }_{23}$ M. Bieniek-Majka: Korzyści i bariery tworzenia grup producentów owoców i warzyw. Roczniki Ekonomiczne Kujawsko-Pomorskiej Szkoły Wyższej w Bydgoszczy (4), 2011, s.11-19.

Zmarlicki K., Brzozowski P., Karmańska M. Analiza efektów ekonomicznych związanych z przynależnością do grupy producenckiej. W: Monitoring i prognozowanie uwarunkowań ekonomicznych produkcji roślin ozdobnych. Instytut Ogrodnictwa. Skierniewice. 2013.

${ }^{24}$ Gąsior R., Nowak A. Integracja pozioma producentów rolnych - możliwości i bariery. Acta Oeconomia (51), 2017

25 D. Olewnicki, L. Jabłońska, M. Marzec: Znaczenie logistyki w grupach i organizacjach producentów owoców na przykładzie powiatów grójeckiego i rawskiego. Roczniki Naukowe Stowarzyszenia Ekonomistów Rolnictwa i Agrobiznesu, 18(5), 2016.

${ }^{26}$ R. Gąsior, A. Nowak Integracja...op.cit, 
Agricultural producers are at the beginning of the food supply chain. Producer organizations are able to control and maintain production quality more than individual producers and to respond to threats. Agro-logistical solutions related to planning, joint supply of associated producers with means of production, joint storage and preparation for sale, distribution and quality control are increasingly used in producer groups. They facilitate the operation of the organization, influence their development and increase their competitiveness ${ }^{27}$.

In Poland, after joining the European Union, the number of producer organizations began to gradually increase, but it is still small compared to other European countries, and individual producers are not competitive due to their small scale of production and a limited range that is not able to meet the needs of recipients. These are undoubtedly the weaknesses of cooperation in Polish horticultural production. The associating farmers, instead of competing with each other, should work together to a greater extent to compete with similar large entities, which is particularly important in the era of globalization.

Table 4. Assessment of the conditions for the functioning of producer groups

\begin{tabular}{|c|c|}
\hline Positive, external conditions & Negative, external conditions \\
\hline $\begin{array}{l}>\text { financial assistance from the European Union } \\
\text { and the State, } \\
>\text { the ability to guarantee large batches of goods } \\
\text { of equal quality for large retail chains, and thus } \\
\text { establish permanent cooperation, } \\
>\text { shorter supply chain, } \\
\text { easier adjustment of the product to customer } \\
\text { expectations, and therefore the possibility of } \\
\text { obtaining higher prices, } \\
>\text { increased competitiveness against large trading } \\
\text { and processing companies, } \\
>\text { a wider, more attractive selection, } \\
>\text { building recognizable brands of producer } \\
\text { groups to which consumers will be loyal }\end{array}$ & $\begin{array}{l}>\text { competition from producers from other EU } \\
\text { countries, } \\
>\text { too much dependence on financial aid that may } \\
\text { cause loss of liquidity, } \\
>\text { the indissolubility of the fruit and vegetable } \\
\text { industry from weather conditions }\end{array}$ \\
\hline Positive, internal conditions & Negative, internal conditions \\
\hline $\begin{array}{l}>\text { cost reduction, access to cheaper means of } \\
\text { production and joint investments, ability to } \\
\text { negotiate price, } \\
>\text { joint search for new markets and marketing } \\
\text { activities, } \\
>\text { easier exchange of experiences and } \\
\text { information, } \\
>\text { greater availability of knowledge, easier } \\
\text { implementation of food quality and safety } \\
\text { systems. }\end{array}$ & $\begin{array}{l}>\text { the reluctance of farmers to form associations, } \\
\text { the desire to maintain independence, } \\
>\text { extensive administration, } \\
>\text { difficulty in making decisions (management) in } \\
\text { the case of groups with a large number of } \\
\text { members, } \\
>\text { difficulty in preparing smaller batches because } \\
\text { of complex technological processes. }\end{array}$ \\
\hline
\end{tabular}

Source: authors' own study based on Zmarlicki i wsp., 2013 i Bieniek-Majka, $2011^{28}$

${ }^{27}$ D. Olewnicki, L. Jabłońska, M. Marzec: Znaczenie logistyki w grupach ...op.cit,

${ }^{28}$ M. Bieniek-Majka: Korzyści.... Op cit.; K. Zmarlicki, P. Brzozowski, M. Karmańska: Analiza efektów... op.cit. 


\section{Summary}

The efficient functioning of fruit and vegetable producer groups is influenced by many factors related to both the conditions of horticultural production, as well as the market situation and appropriate management. The association of horticultural producers entails many benefits and opportunities. One of the chances is usually lowering the costs of means of production or investments. Taking into account the losses on sales generated by the groups, it can be concluded that high production costs are still a big problem in horticultural production. The net financial results are largely dependent on the subsidies. Financial aid is an important element influencing the formation of producer groups. It is considered as an opportunity, and at the same time excessive dependence on it causes a decrease in liquidity, i.e. the ability to pay liabilities on time. The mean values of the liquidity ratios of the studied groups were lower than the recommended values. In recent years, a decline in their profitability has been noticeable, but the cooperation of producers is still a great opportunity for them.

The opportunities and strengths of the functioning of fruit and vegetable producer groups outweigh the number of threats and weaknesses. The manifestations of these positive impulses are only partially reflected in the financial situation of the analyzed groups of fruit and vegetable producers. The revenues of the analyzed groups in 2016-2017 ranged from approx. PLN 1 million up to approx. PLN 65.5 million. Vegetable producer groups were distinguished by higher average revenues than the others. The final financial results varied considerably, from over PLN 2 million net loss at the GPW10 to nearly PLN 1 million profit at GPO4. The average net profit was more favorable for the groups of fruit producers. Fruit and vegetable producer groups in Poland in 2016-2017 had a problem with profitability and liquidity.

\section{Bibliography}

Bednarski L. Analiza finansowa w przedsiębiorstwie. Państwowe Wydawnictwo Ekonomiczne, 2007

Bieniek-Majka M. Korzyści i bariery tworzenia grup producentów owoców i warzyw. Roczniki Ekonomiczne Kujawsko-Pomorskiej Szkoły Wyższej w Bydgoszczy (4), 2011, s. 11-19

Boguta W. Grupy i organizacje producentów owoców i warzyw. Przewodnik praktycznego stosowania obowiązującego prawa (według stanu na dzień 01 września 2004 roku). Wydawnictwo Akademii Rolniczej w Lublinie, 2004.

Chlebicka A., Fałkowski J., Wołek T. Powstawanie grup producentów rolnych a zmienność cen. FAPA. Warszawa. 2008

Domagalska-Grędys M., Czynniki kształtujące zmianę dochodu współpracujących gospodarstw grup producenckich z województwa podkarpackiego. Rocz. Nauk Roln. 97, 4, 2010, s.45-53

Dyktus J., Gaertner M., Malik B. Sprawozdawczość i analiza finansowa. Difin, 2017

Gąsior R., Nowak A. Integracja pozioma producentów rolnych - możliwości i bariery. Acta Oeconomia (51), 2017

Hardaker J.B., Huirne R.B.M., Anderson J.R., Lien G. Coping with Risk in Agriculture. CABI Publushing. Wallingford, 2004

Kania J., Musiał W. Dodawanie wartości w łańcuchach dostaw żywności-studium przypadku. Roczniki Naukowe Stowarzyszenia Ekonomistów Rolnictwa i Agrobiznesu, 19(6), 2017, s.105-110

Klepacki B., Krajewski J. Wykorzystanie środków pomocowych unii europejskiej w rozwoju infrastrtury logistycznej grup producenckich w ogrodnictwie. Roczniki Naukowe SERIA XVII (5), 2015, s. 136-140.

Leszko D. Organizacja unijnego rynku owoców i warzyw oraz konieczność dostosowania w Polsce. FAPA. Warszawa, 2000 
Lipińska I.. Rola integracji poziomej w ograniczaniu występowania ryzyka produkcyjnego w kontekście reformy wspólnej polityki rolnej - aspekty prawne i ekonomiczne. Roczniki Naukowe SERIA XVI (5), 2014, s.139-145

Malinger J. Wynikiekonomiczneuznanychorganizacjiproducentówjabłek z powiatugrójeckiego. Roczniki Naukowe SERIA, XVIII(1), 2016, s. 169-173.

Małysz J. Integracja w Agrobiznesie. W: A. Woś (red.) Encyklopedia Agrobiznesu, Fundacja Innowacja. Warszawa, 1998 s. 389-391

Martyniuk T. Przychody jako kategoria prawa bilansowego. Zeszyty Teoretyczne Rachunkowości, 54. 2010, s.117-128.

Olewnicki D., Jabłońska L., Marzec M., Znaczenie logistyki w grupach i organizacjach producentów owoców na przykładzie powiatów grójeckiego i rawskiego. Roczniki Naukowe Stowarzyszenia Ekonomistów Rolnictwa i Agrobiznesu, 18(5), 2016.

Olewnicki D. Rybak J. Rodzaje uprzedzeń właścicieli gospodarstw ogrodniczych do zrzeszania się w grupy producentów - przykład gminy Błędów Zeszyty Naukowe SGGW - Ekonomika i Organizacja Gospodarki Żywnościowej, 101, 2013, s. 129-138

Sobczak W., Jabłońska L., Dziedzic A. Wybrane problemy funkcjonowania grup producentów owoców z regionu grójeckiego i rawskiego. Journal of Agribusiness and Rural Development, $(03,29), 2013$.

Stefko O. Płynność finansowa gospodarstw ogrodniczych a zmiany zachodzące na rynku międzynarodowym. Problems of World Agriculture/Problemy Rolnictwa Światowego, 16, 2016, s. 325-334.

Szałata Ł., Zwoździak, J. Analiza SWOT jako podstawowe narzędzie w zarządzaniu środowiskiem. Rocznik Ochrona Środowiska (Annual Set The Environment Protection), 13, 2011, s. 1105-1114.

Załuska K.. Grupy wstępnie uznane i organizacje producentów na rynku owoców i warzyw w Polsce, Europie i na świecie. W: ABC organizacji i funkcjonowania grup producenckich. CDR w Brwinowie oddział w Radomiu, 2010

Zmarlicki K., Brzozowski P., Karmańska M. Analiza efektów ekonomicznych związanych z przynależnościa do grupy producenckiej. W: Monitoring i prognozowanie uwarunkowań ekonomicznych produkcji roślin ozdobnych. Instytut Ogrodnictwa. Skierniewice. 2013.

\section{Ocena sytuacji ekonomiczno-finansowej oraz analiza strategiczna działań grup producentów owoców i warzyw w Polsce}

\section{Streszczenie}

Polska zajmuje wysokie miejsce w światowej i europejskiej produkcji owoców oraz warzyw. Jednym z problemów polskiego rolnictwa jest nadal, choć w nieco mniejszym stopniu rozdrobnienie. Pomoc krajowa i unijna sprawiła, że wśród producentów wzrosło zainteresowanie zrzeszaniem się w grupy producenckie. Ich funkcjonowanie uwarunkowane jest wieloma czynnikami związanymi ze specyfiką produkcji ogrodniczej, z obowiązującym prawodawstwem czy sytuacją rynkową. Organizacje na rynku owoców i warzyw wykazują znaczne zróżnicowanie w funkcjonowaniu jak również w osiąganych wynikach produkcyjno-ekonomicznych.

Celem artykułu jest ocena sytuacji finansowo ekonomicznej oraz analiza strategiczna uwarunkowań działania grup producentów owoców i warzyw w Polsce. Dokonano jej na podstawie danych zawartych w sprawozdaniach finansowych wybranych grup z lat 2016-2017 oraz obliczonych na ich podstawie wskaźników finansowych płynności i rentowności. 
W opracowaniu przedstawiono także analizę strategiczną SWOT dla organizacji i grup producentów. W badanych latach odnotowano niską rentowność i płynność finansową badanych grup. Za kluczowe o znaczeniu strategicznym dla funkcjonowania omawianych podmiotów należy zaliczyć takie czynniki jak: widoczny wpływ pomocy finansowej na funkcjonowanie grup producenckich oraz korzyści skali wynikające z większej agregacji konkurencji z drugiej strony. Rolnicy nadal niechętnie się zrzeszają i często posiadają ograniczone kompetencje biznesowe do prowadzenia grup producenckich.

Słowa kluczowe: grupy producentów, organizacje producentów, rynek owoców i warzyw, analiza finansowa, analiza wskaźnikowa

JEL Codes: D22, D24,Q14, Q13

Information about the authors:

Dr inż. Dagmara Stangierska, Warsaw University of Life Sciences Institute of Horticultural Sciences Nowopursynowska Street 159, 02-776 Warsaw, dagmara.stangierska@sggw.edu.pl ORCID: 0000-0002-8104-0527

Dr inż. Dawid Olewnicki,

Warsaw University of Life Sciences Institute of Horticultural Sciences Nowopursynowska Street 159, 02-776 Warsaw, e-mail: dawid_olewnicki@sggw.edu.pl ORCID: 0000-0002-3096-3882

\section{Mgr inż. Ewa Sabała}

